IN brief

\section{Japanese pharmas unite for poorest}

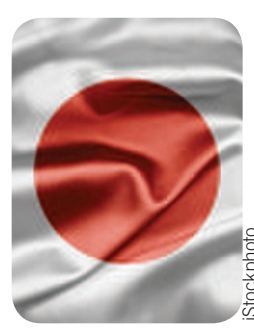

On April 8, Japan launched its first public-private partnership aimed at reducing the burden of infectious diseases in the developing world. The \$100-million Tokyobased Global Health Innovative Technology Fund will support collaborative research projects that promise drugs, vaccines and diagnostics for tackling HIV, malaria, tuberculosis and neglected tropical diseases such as lymphatic filariasis. The fund's annual budget of \$20-30 million has a five-year commitment from all investors. In the first year, the Japanese government will invest $\$ 11$ million; the Bill \& Melinda Gates Foundation, around $\$ 5$ million; and Japanese pharma companies, \$1 million each. Eisai, headquartered in Tokyo, established the global health fund and five other Japanese pharma companies signed up, including Astellas, Daiichi Sankyo, and the Drugs for Neglected Diseases Initiative (DNDi) Japan, all based in Tokyo, and Shionogi and Takeda, based in Osaka. The companies were "the catalytic force" in driving the fund, says B.T. Slingsby, the fund's executive director, and formerly head of global strategy for developing markets at Eisai, the Tokyo-based pharma. "This is not for profit; we invest public goods. However, there are myriad benefits for our partner companies including alignment and synergies with growth strategies in the developing world." The money will support research collaborations between pharma companies with a research base in Japan, Japanese and foreign academic researchers and biotech firms, and international nonprofit organizations. Some Japanese companies already pursue such diseases. Eisai, for example, has been developing drugs for Chagas disease and leishmaniasis. But this will be the first nationwide effort. "Over the past ten years or more, such funds have been very active in the United States and Europe, but in Japan there has been nothing," says Hiroyuki Hori, deputy director of the health ministry's international affairs division in Tokyo. "We want to correct that." Slingsby says they expect to fund two or three interventions that can finish development within five years. The deadline for applications is June 15, and winners will be selected in August.

David Cyranoski

\section{IN their words}

"Twelve years ago about half the value of the stock price was in the pipeline ... (today) it could be $20 \%$." Fred Hassan, of the private equity firm Warburg Pincus of New York (formerly CEO of Schering-Plough and Pharmacia). Hassan says the industry is slowly turning but needs to do better. (Reuters, 8 May 2013)
Among the highest profile family offices is Microsoft billionaire Bill Gates' investment business, which in 2011 helped seed computational drug discovery biopharma Nimbus Discovery of Cambridge, Massachusetts, and whose Bill \& Melinda Gates Foundation in late 2012 contributed to influenza startup Cambridge, Massachusetts-based Visterra’s \$13-million A round.

It's easy to see why Ford, in his blog (http:// blog.lifesciencenation.com/2012/12/10/ family-offices-the-new-vcs-2/), labels family offices as "the new VCs." That may be wishful thinking, though; families aren't about to fill the void left by the shrinking VC base, according to Bruce Roberts. For one thing, they can't sustain a VC-style deal throughput. "They might do one deal a year," he notes. Still, with many prepared to stump up anything from $\$ 1-2$ million to $\$ 5-10$ million or more per investment over several years, they can mean the difference between success or failure for individual startups.

As such, Roberts acknowledges the growing role for family offices as a supplement to traditional venture capital-just as corporate $\mathrm{VC}$ and venture philanthropy has become in the past five years. In 2011, six out of seven venture deals closed by Roberts Mitani involved family-backed investment vehicles, according to Roberts. In mid-2012, medical device spin-out ValCare of Irvine, California, landed $\$ 8$ million from Accelmed, founded and backed by Israeli entrepreneurs Mori Arkin and Uri Geiger.

The ValCare example illustrates how larger family offices can afford to take on riskier deals, and often with fewer constraints, than traditional venture capitalists. That company "wasn't readily fundable by VC because it is early-stage and the field is so competitive," notes Roberts. "It needed someone with the resource to take the risk, and the sophistication to compare ValCare's technology to all the other [mitral valve] technologies out there."

And whatever their appetite for risk, family offices are often willing and able to commit for the long term, unconstrained by the need to exit investments at the end of a fund's life. "There's less pressure to show a return within just a few years," notes Ruth Devenyns, a former biotech analyst and investment banker who in mid-2012 joined Korys, the family office of Belgian retail entrepreneurs the Colruyts, to help them expand their activities into the life sciences. "It's a different [investment] philosophy" from that of venture capitalists, Devenyns continues. Among Korys' first two investments in biotech is Biocartis, a Lausanne,
Switzerland-based molecular diagnostics group, which raised a major portion of its $€ 95$ (\$122.5) million from European family offices.

Granted, the flip side is that family office priorities, passions or circumstances may change, "and they may not be there in three years' time with reserve funds for follow-on financing," warns one venture capitalist who preferred to be unnamed.

By and large, though, family offices are a welcome addition to the sparse early-stage funding landscape. "We'd love to have family office money for patient capital over the long run, to help us build companies," notes Bruce Booth, partner at Atlas Venture in Cambridge, Massachusetts, which just closed a \$265-million fund to support seedand early-stage life sciences and technology firms.

Some family offices are indeed taking on limited partner roles. Michiel de Haan, general partner and co-founder at Amsterdambased Aescap Venture, claims that at least $30 \%$ of Aescap's fund is from family offices, none of which have backgrounds in life sciences. (They include the Brenninkmeijers, the family behind global retail chain C\&A, for instance.) Three of those offices have also invested directly in portfolio companies. "They get experience of the sector through investing in the Aescap fund, and then gain the confidence to invest directly" on top, he explains. De Haan also highlights the importance of wealthy individuals - those who don't quite qualify as family offices, but rather are deep-pocketed angels-in bridging companies from government subsidy to venture capital.

Still, although family offices are gaining prominence, we're not talking about a stream of easy money that risks creating the kind of bubble seen in 1990s Germany as a result of a flood of government support for startups. For obvious reasons, family offices (and other wealthy individuals) tend to be quite secretive and cautious of approaches compared with angels and venture capitalists. Rock Spring Ventures' Dunlop also cautions that he hasn't "seen a critical mass of family offices chomping at the bit" to make life sciences investments. He's confident, though, he'll succeed in bringing one or two family offices into his fund, but "it's an uphill battle."

One reason that it is a struggle is that there are plenty of other high-growth sectors competing for wealthy families' funding - those same sectors, such as social media or renewable energy, whose apparently lower-risk profile and (in the case of social media) 